Izvorni znanstveni rad

DOI: $10.17234 /$ Croatica.42.15

UDK: 811.163.42'35:81'367.633

Primljen: 15. I. 2018.

Prihvaćen: 6. II. 2018.

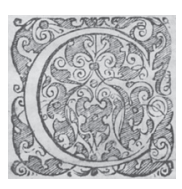

\title{
NADOHVAT, NADOMAK, UIME I USUSRET - PRAVOPISNO BILJEŽENJE PRIJEDLOŽNIH TVORENICA U HRVATSKOM JEZIKU
}

\author{
Ermina Ramadanović \\ Institut za hrvatski jezik i jezikoslovlje \\ Ul. Republike Austrije 16, 10000 Zagreb \\ eramadan@ihjj.hr
}

U ovome je radu riječ o bilježenju prijedloga u hrvatskim jezičnim priručnicima, ponajprije u onim pravopisnim. Proučavat će se samo neki (odabrani) pravopisno upitni prijedlozi, a njihov se opis i raščlamba temelje na nekoliko jezičnih aspekata. Polazište je pravopisno poglavlje o sastavljenom i nesastavljenom pisanju. S obzirom na to da je problem razgraničenja jedne riječi (prijedloga) od više riječi (prijedložnoga izraza), zapravo pravi jezični (tvorbeni, morfološki i sintaktički), a tek onda pravopisni problem, potrebno je bilo ući i u jezičnu raščlambu. Dakle ponajprije se istražuje propis u vezi s četirima prijedložnim tvorenicama te se on stavlja u suodnos s njihovim opisom i popisom, a nakraju i s jezičnom uporabom.

Ključne riječi: hrvatski jezik, pravopis, sastavljeno i nesastavljeno pisanje, prijedlozi, prijedložni izrazi 


\section{UVOD}

Rad se bazira na istraživanju koje je obuhvatilo hrvatske pravopise ${ }^{1}$ od onih najstarijih - pritom se misli na pravopise u kojima se osim prikaza sustava latiničkih slova pokušavaju riješiti i neka od temeljnih pravopisnih pitanja (onih u užem smislu), pa se u tom smislu krenulo od Partaševa pravopisa (1850) i Kušarova pravopisa (1889) do najnovijih izdanja suvremenih pravopisa $^{2}$ : Anić-Silićeva Pravopisa hrvatskoga jezika (2001), Babić-Finka-Moguševa Hrvatskoga pravopisa (2004), Babić-Ham-Moguševa Hrvatskoga školskog pravopisa (2008), Badurina-Marković-Mićanovićeva Hrvatskoga pravopisa (2007), Babić-Moguševa Hrvatskoga pravopisa (2010) te Hrvatskoga pravopisa Instituta za hrvatski jezik i jezikoslovlje (2013) ${ }^{3}$. Težište je stavljeno na pravopisno poglavlje koje se bavi sastavljenim i nesastavljenim pisanjem. ${ }^{4} \mathrm{Za}$ sastavljeno i nesastavljeno pisanje problem je identifikacije i definicije riječi upravo najveći problem. Kad naime znamo što je jedna riječ, odnosno što su dvije riječi, onda nam tu jednu ili dvije riječi nije teško ni napisati. Jedan je od najvećih problema prema Pranjkovićevu (2002) mišljenju taj što ima veoma mnogo slučajeva u kojima je teško utvrditi je li riječ o jednoj ili dvjema riječima "pored ostaloga i zato što se, po svojoj prilici, može govoriti o prijelaznim slučajevima između riječi i ne-riječi” (Pranjković 2002: 53).

1 U obzir nisu uzeta sva izdanja pravopisnih knjiga, nego samo iz onih koja su označila kakvu prekretnicu u vremenu (društveno-povijesna zbivanja) ili pak prekretnicu u pravopisnoj normi. Više o tome v. Badurina (1996) i Ramadanović (2012).

2 Proučavane prijedložne tvorenice nadohvat, nadomak, uime i ususret nisu zabilježene u Partaševu i Kušarovu pravopisu.

3 Ministarstvo znanosti, obrazovanja i sporta Republike Hrvatske 31. srpnja 2013. godine izdalo je preporuku za uporabu Hrvatskoga pravopisa Instituta za hrvatski jezik i jezikoslovlje u osnovnim i srednjim školama Republike Hrvatske.

4 Taj je naziv prvi uporabio Pranjković (2003) u radu Opća načela sastavljenoga i nesastavljenoga pisanja. U međuvremenu taj je naziv upotrijebljen za naslov poglavlja dvaju pravopisa: $\mathrm{u}$ Hrvatskom pravopisu MH $\left({ }^{12007,}{ }^{2} 2008\right)$ i u Hrvatskom pravopisu IHJJ-a (2013). O naslovu koji se najčešće provlači kroz novije hrvatske pravopise - Sastavljeno i rastavljeno pisanje riječi - treba reći da je zapravo veoma nespretan jer se riječ ne može pisati rastavljeno. Sastavljeno se pišu dijelovi riječi (s tvorbenoga gledišta tvorbene sastavnice ili s morfološkoga gledišta morfemi), a kad se što piše nesastavljeno ("rastavljeno") ili između dviju bjelina, to je onda riječ, dvije riječi ili više riječi. Slažemo se s Pranjkovićevim mišljenjem (2003) te napominjemo da se riječ (pridjev) nesastavljeno, u odnosu na rastavljeno, čini boljom oprekom riječi sastavljeno. Naime prefiksom ne-dobiva se prava semantička suprotnost osnovnoj riječi, tj. njime se niječe osnovno značenje riječi kojoj se prefiks ne-dodaje. 
Pravopisno upitni slučajevi ${ }^{5}$ posebno su istraženi prema sekundarnom korpusu, tj. prema potvrđenosti u suvremenim rječnicima hrvatskoga jezika (v. Popis izvora), u Rječniku hrvatskoga ili srpskoga jezika ${ }^{6}$, u savjetnicima, gramatikama i ostalim dostupnim izvorima, primjerice u reprezentativnom mrežnom korpusu hrvatskih tekstova Hrvatska jezična riznica ${ }^{7}$ Instituta za hrvatski jezik i jezikoslovlje (http://riznica.ihjj.hr).

U hrvatskim se jezičnim priručnicima tvorba ${ }^{8}$ prijedloga uopće ne spominje u poglavljima o tvorbi riječi. ${ }^{9}$ Treba međutim naglasiti da se $\mathrm{i}$ prijedlozi mogu tvoriti na nekoliko načina te da njihov nastanak i njihova tvorba još uvijek traje. Obradba je prijedloga u jezičnim priručnicima obično smještena unutar poglavlja o morfologiji. Prijedlozi se po postanku najčešće dijele na prave (primarne), izvedene, neprave (sekundarne) i složene (v. HG 1995: 278). ${ }^{10}$ Pravi ili netvorbeni prijedlozi oni su koji služe samo kao prijedlozi, a njihovo se značenje ne može izvesti ni iz koje druge riječi, npr. bez, do, iz, na, nad, niz, o, pri, $s, u, z a$ i sl. Nepravi su prijedlozi zapravo nastali tvorbom riječi, a dijele se na izvedene i složene. Dio prijedloga nastaje preobrazbom ${ }^{11}$ (od imenica - akuzativ: čelo, dno, duž, kraj, mjesto, put, sred, vrh i sl.; instrumental: pomoću, posredstvom, putem, silom i sl.; od priloga: blizu, niže, širom, više i sl.). U Silićevoj i Pranjkovićevoj gramatici (GHJ 2005: 242) prijedlozi se dijele na proizvedene (motivirane) i neproizvedene (nemotivirane).

\footnotetext{
5 To su oni slučajevi u kojima se pravopisna norma razlikuje u kojemu od pravopisnih priručnika.

6 Rječnik hrvatskoga ili srpskoga jezika. 1880-1976, I-XXIII. JAZU. Zagreb. U daljnjem tekstu AR.

7 Svi primjeri iz toga su korpusa ekscerpirani u razdoblju od 15. rujna 2010. do 9. listopada 2016. godine.

8 Pitanje sastavljenoga i nesastavljenoga pisanja pitanje je koje se "osim na prosudbi jezičnog materijala, temelji i na teorijskim, lingvističkim, promišljanjima, ponajprije o tvorbi riječi" (Badurina 1996: 83), ali sva bi jezična istraživanja, pa i ona koja se odnose na tvorbu riječi trebalo riješiti izvan pravopisa (v. Minović 1976: 233).

9 U novije vrijeme vidi radove Horvat i Ramadanović (2007) i Ramadanović (2012).

10 Prijedlozi zapravo većinom nastaju preobrazbom. Primjere poprjedloženja u Hrvatskoj gramatici nalazimo u poglavlju Morfologija, a naziva ih se nepravim prijedlozima jer nastaju od drugih vrsta riječi upotrijebljenih u funkciji prijedloga.

11 U Hrvatskoj gramatici navodi se da nastaju "okamenjivanjem kakvog oblika imenice" i "među izvedene prijedloge ubrajaju se i one riječi koje se upotrebljavaju i kao prilozi (uz glagole) i kao prijedlozi (uz imenice)" (HG 1995: 278). Ovdje se ne bavimo pisanjem pravih (netvorbenih) prijedloga i preobrazbom jer u vezi s njima nema nedoumica u pisanju.
} 


\section{PRAVOPISNO UPITNI PRIJEDLOZI}

U hrvatskim je pravopisima zapravo veoma malo prijedloga u kojima pravopisna norma nije dokraja usklađena. U svima je od njih riječ o prijedlozima morfološki strukturiranima od prijedloga i imenice u nekom padežnom obliku. ${ }^{12} \mathrm{U}$ pravopisima se za takve prijedložne izraze ${ }^{13}$ obično navodi jedno veoma subjektivno pravilo koje kaže da ako se imenici u sastavu prijedložnoga izraza više ne osjeća njezino pravo značenje ${ }^{14}$, onda dolazi do nastanka nove riječi (tvorenice) te pravilo koje počiva na morfološkom načelu, a koje kaže da se sastavljeno pišu oni (prijedložni) izrazi u kojima se jedna od riječi (najčešće je riječ o imenici) ne nalazi u onom gramatičkom obliku u kojemu bi trebala stajati prema prijedlogu ispred nje. Isto se navodi i za novonastalu tvorenicu, tj. da dijelovi koji ulaze u sastav koje tvorenice nastale od prijedložnoga izraza moraju imati novo, drukčije značenje. Prema ekscerpiranim primjerima iz hrvatskih pravopisa vidljivo je da pravopisna norma nije usklađena u pisanju veoma maloga broja prijedloga, odnosno prijedložnih izraza. ${ }^{15} \mathrm{U}$ ovome ćemo se radu osvrnuti samo na ove pravopisno upitne prijedloge, odnosno prijedložne izraze u funkciji prijedloga: nadohvat / na dohvat, nadomak / na domak, uime / u ime i ususret / u susret.

\subsection{Nadohvat / na dohvat i nadomak / na domak}

Nadohvat i nadomak prijedlozi su koji dolaze uz dativ, ali i uz genitiv, iako se preporučuje njihova uporaba s dativom. Dativ je padež koji u hrvatskom jeziku teži besprijedložnoj uporabi (najviše se to očituje u razgovornom stilu), suprotno dakle od lokativa (v. GHJ 2005: 221).

Sastavljeno pisanje nadohvat (tvorbene sastavnice: $n a-+-d o h v a t$ ) zabilježeno je kao prijedlog ili kao prilog u ovim pravopisima: 1934: Boranić

12 Tvorbeni opis tako nastalih prijedloga može biti ovakav: nadomak se može smatrati prefiksalno-sufiksalnom tvorbom: na- + -domak- + -ø (v. tvorbu priloga, GHJ 2005: 180), srastanjem, slaganjem, prefiksacijom te prefiksalno-preobrazbenom tvorbom. U kojim se priručnicima $\mathrm{i}$ kod kojih autora smatraju jednim od navedenih tvorbenih načina v. Ramadanović (2014). Isti je slučaj i s prijedlozima nadohvat, nakraj, ususret i sl.

13 Nije naodmet spomenuti da je isti slučaj i s nastankom priloga.

14 Taj se semantički, ali i morfološki, kriterij javlja još od Brozova pravopisa (1892). V. Badurina (1996: 89) i Ramadanović (2012).

15 V. Ramadanović (2012: 657). 
pril.; 1951: Boranić prij.; (PP) nadohvat(u); 1960: MH - MS prij. nädohvāt i nadò vat (nadohvat ruke); 1971: BFM pril.; 1986: AS Stoji pored mene nadohvat ruke.; 2001: AS; 2007: BMM prij.; 2013: HPIHJJ prij.

Nesastavljeno pisanje ili prijedložni izraz na dohvat propisan je u ovim pravopisima: 1996: BFM (PP) dijelovi izreke, 2000: BFM (PP) dio fraz.; biti na dohvat; 2008: BHM; 2010: BM (PP) (fraz.) biti na dohvat; (PR) pod dohvat. U svim je navedenim pravopisima taj prijedložni izraz propisan u pravopisnim pravilima koja se odnose na pisanje priloga.

Imenica dohvat pravopisno nije upitna, ali je zabilježena u onim pravopisnim rječnicima koji propisuju prijedložni izraz, tj. ona služi kao potvrda samostalnoga postojanja, odnosno kao potvrda semantičkoga načela: 1960: MH - MS im.; 1996: BFM na dohvat; 2000: BFM na dohvat; 2008: BHM: na dohvat; 2010: BM na dohvat ruke.

U Aniću i HER-u nadohvat je jedna natuknica koja je i prilog i prijedlog. Nadohvat je najprije prilog koji znači 'blizu, nadomak', a prijedlog je zabilježen ovako: nàdohvāt (II) prij. 1. (s G) blizu 2. (s D) nadomak [ ruci]. Anić i HER bilježe imenicu dohvat sa značenjem 'razmak ili udaljenost s koje se može dohvatiti' s frazemom biti na dohvat ruke 'biti posve blizu'. U HJS-u nadohvat je prijedlog i prilog. U AR-u nalazi se samo imenica dohvat. U AŠR-u nadohvat je prijedlog. ${ }^{16}$ Zanimljivo je da se u frazeološkom dijelu natuknice rúka (HER) nalaze ovi frazemi: $\diamond$ biti na dohvat ruke biti blizu, pristupačan (u smislu udaljenosti); blizu, nadohvat ruke biti blizu, ne biti daleko; na dohvat ruke vrlo blizu. Dvojba se dakle još više produbljuje navođenjem frazema u koje jednom ulazi prijedlog, a drugi put prijedložni izraz u prijedložnoj funkciji (s istim značenjem). Riječ je dakle o istoj jezičnoj jedinici, ali s različitim zapisom. ŠR također bilježi tvorenicu nadohvat kao prijedlog. U HG-u nadomak je prijedlog (1995: 279).

U korpusu HJR-a potvrđeno je 117 primjera sastavljenoga pisanja nadohvat i 116 primjera nesastavljenoga pisanja na dohvat. Dobiveni rezultat pokazuje da je brojčana razlika zapravo neznatna i zanemariva te da se mora ići u dublju raščlambu. Pisanje na dohvat obično se opravdava činjenicom da je taj prijedložni izraz dio frazema biti na dohvat ruke. Naime u korpusu je zabilježen 61 primjer nesastavljenoga pisanja skupa riječi na dohvat ruke (prijedložni izraz i imenica) i 90 primjera za prijedlog i imenicu:

16 O naglasnoj normi nekih od proučavanih prijedloga (npr. nadohvat, nadomak...), tj. o odnosu pravopisnih pravila prema pravogovornome planu v. Matešić i Ramadanović (2017). 
nadohvat ruke. U korpusu je dakle 117 primjera za tvorenicu nadohvat, a njih 90 odnosi se na prijedlog nadohvat u frazemu nadohvat ruke. Činjenica je dakle da je frazem (biti) nadohvat ruke (s prijedlogom, a ne prijedložnim izrazom u prijedložnoj funkciji) potvrđen u više primjera. I što je važnije, frazem ne prestaje biti frazemom ako se u njemu nalazi prijedlog nadohvat jer i dalje u njemu supostoje najmanje dvije sastavnice (riječi). Prijedlog nadohvat ili prijedložni izraz na dohvat iza kojih slijedi riječ u genitivu ili dativu u rečenici najčešće ima funkciju priložne oznake mjesta. S druge strane, u korpusu HJR-a potvrđeni su i primjeri u kojima prijedložni izraz na dohvat nije frazemska sastavnica, tj. on se upotrebljava i izvan frazema. Prijedložni izraz u prijedložnoj funkciji može biti i u postpoziciji (primjer 1b) dok, s druge strane, tvorenica (jednorječnica) nadohvat u korpusu nije zabilježena u postpoziciji. "Većina prijedloga dolazi ispred riječi na koje se odnose, a samo rijetki među njima mogu dolaziti i iza tih riječi, pa se katkada nazivaju i poslijelozima, npr. Sve bi učini zdravlja radi ili Radio je svim usprkos" (GHJ 2005: 244). ${ }^{18}$

(1a) Jedva na dohvat jedne serpentine. (Begović 1999. (1940))

(1b) $[\ldots]$ koje bi mu padale očima na dohvat, uskrisujući u njemu čislo milih uspomena [...] (Car Emin 1900)

(1c) A ono nije daleko. Na dohvat pogleda. (Barković 1958)

(1d) [...] dakako, na dohvat otimačini i propasti, — prtljaga! (Batušić 1941)

U korpusu su uočeni i primjeri u kojima je nadohvat prilog (2a, 2b), tj. na dohvat je priložni izraz, odnosno prijedložni izraz u priložnoj funkciji (2c).

(2a) Nekoliko se puta čini da je povratak tu, nadohvat, zatim se opet odgađa, udaljuje, nada raste i odmiče se [...] (Selem 2002)

(2b) Na to možemo biti ponosni i sada smo puno bliže NATO-u nego smo ikada bili. Praktički nadohvat. (Vjesnik 2003)

(2c) Pročitao sam, na dohvat i bez reda, kao što sve i uvijek čitam, nekoliko knjiga o postanku i povijesti religija. (Desnica 1957)

17 Blagus Bartolec i Matas Ivanković (2013: 366) također navode da se sinonimni prijedlozi nadohvat i nadomak te ususret mogu naći u postpoziciji, ali se nakon toga prijedlog nadohvat oprimjeruje prijedložnim izrazom na dohvat.

18 Poslijelozima se u gramatikama obično navode ovi prijedlozi: radi, nasuprot, unatoč, uprkos, usprkos. (Blagus Bartolec i Matas Ivanković 2013: 365). 
Korpus pokazuje i da se između frazemskih sastavnica nadohvat ruke može umetnuti i koja druga riječ, npr. pridjev: "Sulejman ne pokaza ni da je čuo, ali tjelohranitelj, koji je držao sablju sultanu nadohvat desne ruke [...]" (Aralica 1979).

U Boranićevu pravopisu iz 1951. navodi se natuknica: nadohvat(u), tj. razumijevaju se dvije inačice: nadohvat i nadohvatu. U korpusu HJR-a nije međutim potvrđen nijedan primjer sastavljenoga pisanja nadohvatu, a prijedložno-padežni izraz na dohvatu u korpusu je zabilježen u 88 primjera.

U korpusu HJR-a potvrđeno je 124 primjera imenice dohvat te samo jedan primjer u kojemu imenica dohvat dolazi bez prijedloga na: "Bitak sam, otkrivajući se u postojećim stvarima i u mišljenju, ujedno se neuhvatljivo usteže i skriva za svaki dohvat i uskraćuje se kategorijalnome mišljenju, koje pak bez njega ne bi bilo moguće" (Cipra 1999). Potvrđena su i dva primjera u kojima prijedložni izraz na dohvat nije u prijedložnoj funkciji:

(3a) Vlado, još mrk i prestrašen, uprkosi glavu, pa kad mu se Minja primakao na dohvat, snažno zamahne pleskom. (Laušić 1960)

(3b) [...] i kako apatekar dosrnu na dohvat, zamahnu Mara, da su stakla prozora za njom išla na komade [...] (Šenoa 1885)

Iz navedenih je primjera (3a i 3b) teško zaključiti je li riječ o prijedložno-padežnim izrazima ili, drugim riječima, o prijedložnim izrazima u osnovnom značenju prijedloga i imenice ili je ipak riječ o priložnim izrazima, tj. o prijedložnim izrazima u funkciji priloga.

Općeprihvaćeno je pravilo hrvatskih pravopisa da se sastavljeno pišu jezične jedinice koje se nikad ne pojavljuju samostalno. Činjenica je da se imenica dohvat gotovo nikad ne upotrebljava samostalno, da se uvijek pojavljuje uz prijedlog $n a$ te da je najčešće riječ o frazemskoj sastavnici. Na takve bi se slučajeve moglo primijeniti ono opće pravilo koje kaže da se sastavljeno piše "skup kojemu jedan ili oba sastavna dijela ne postoje kao samostalne riječi” (BFM 1996: 77), ali i "skup u kojemu se jedan sastavni dio ne upotrebljava uz drugi u onom obliku koji ima u složenici” (BFM 1996: 77), pa bi prijedložni izraz bio na dohvatu, a tvorenica (prijedlog ili prilog) nadohvat. Prijedlogu nadohvat sa značenjem 'u velikoj blizini koga ili čega' sinonimni su prijedlozi blizu, nadomak, pokraj i sl.

Prijedlog nadomak veoma je sličan, i strukturno i semantički, prijedlogu nadohvat. Morfološki se sastoji od prijedloga na i akuzativa imenice domak, a tvorbeno od tvorbene sastavnice $n a$ - i tvorbene osnove -domak.

Sastavljeno pisanje nadomak (na- + -domak) propisano je u ovim pravopisima: 1904: BB prij.; 1906: BB prij.; 1921: Boranić prij.; 1928: Boranić 
prij.; 1930: Boranić (PP) prij.; 1934: Boranić prij.; 1941: Boranić prij.; 1941: CGK prij.; 1944: CK pried.; 1951: Boranić prij.;(PP) nadomak(u); 1960: MH - MS (PP) prij.; nadòmak selu; 1971: BFM pril.; 2001: AS; 2007: BMM prij.; 2013: HPIHJJ prij. Zanimljivo je da je u BFM-u iz 1971. nadomak prilog.

Nesastavljeno pisanje na domak propisano je u ovim pravopisima: 1996: BFM (PP) dijelovi izreke; (PR) biti na domak ruke; 2000: BFM (PP) dio fraz.; biti na domak; (PR) pod domak; 2008: BHM pod domak; 2010: $\mathrm{BM}(\mathrm{PP})$ (fraz.) biti na domak.

Poput imenice dohvat u pravopisnim se rječnicima, iako nije pravopisno upitna, bilježi i imenica domak: 1960: MH - MS im. 'dohvat, doseg'; piše se zajedno s prijedlogom: nadomak, nadomaku; 1996: BFM im. 'dohvat, domašaj'; 2000: BFM (dohvat, domašaj), biti na domak ruke; 2008: BHM biti na domak ruke; 2010: BM 'dohvat, domašaj'; biti na domak ruke.

Imenicu domak bilježe Anić i HER sa značenjem 'daljina dokle se može dosegnuti, dohvatiti; domašaj', s prijedložnim izrazom na domak 'blizu'. Anić i HER bilježe jednu natuknicu nadomak za prilog i prijedlog: nadòmak (II) prij. (s G) vrlo blizu. U HJS-u nadomak je samo prijedlog. AR uz imenicu domak navodi da dolazi "samo kao adverab" s prijedlogom na: na domak ("pisano i nadomak"). U AŠR-u nadomak je prijedlog, a tako je i u ŠR-u.

U korpusu postoji 661 potvrda tvorenice nadomak, a prijedložni izraz na domak potvrđen je u 44 primjera. Od 661 primjera tvorenice nadomak, pronađena su tri primjera u kojima je nadomak prilog:

(4a) Nikad i nisam prežalio veliku prigodu kojoj smo bili nadomak samo da smo poslije naših 1-0 početkom nastavka još koju minutu sačuvali loptu [...] (NA. Vjesnik online)

(4b) Zamislite da se mostarski »Aluminij« mora koristiti barskom lukom, a ne Lukom Ploče, koja mu je nadomak. (NA. Vjesnik online)

(4c) Znamo koja nam je sreća nadomak, a trener nas zna usmjeriti na prave ciljeve. (NA. Vjesnik online)

Prijedlog nadomak u korpusu HJR-a potvrđen je i u postpoziciji: ${ }^{19}$ "Netko bi rekao da su to samo jalni krici onih koji nisu uspjeli ušetati u Banske dvore, a bili su im nadomak [...]" (NA. Vjesnik online)

Uporabu imenice domak možemo vidjeti u korpusu u prijedložnom izrazu na domaku koji je potvrđen u 58 primjera, dok je tvorenica nado-

19 Prije smo pokazali da prijedlog nadovat u korpusu HJR-a nije potvrđen u postpoziciji, dok prijedložni izraz na dohvat jest. 
maku potvrđena u jednom primjeru: "Evo ga već nadomaku, i posljednja je pokljuka zgotovljena. Korajac. ${ }^{20}$ Polovica primjera prijedložnoga izraza iz korpusa ima otprilike prijedložnu (26 primjera), a druga polovica ima priložnu funkciju.

Hrvatski jezični priručnici, ponajprije pravopisi pokazuju da su tvorenice nadohvat i nadomak bile dijelom hrvatske pravopisne tradicije do BFM-a (1996). Nesastavljeno se pisanje u tom pravopisu opravdava time da se taj izraz, ali i mnogi drugi, "upotrebljavaju kao dijelovi izreke" (BFM 1996: 80) ili u BFM-u (2000: 82) i u izdanjima poslije tog kao "dio frazema": biti $n a$ dohvat i biti na domak. U hrvatskoj je frazeologiji općeprihvaćeno mišljenje da frazem mora imati najmanje dvije sastavnice. Činjenica je međutim da prijedložni izraz na dohvat i tvorenica nadohvat te prijedložni izraz na domak i tvorenica nadomak sami po sebi nisu frazemi. Frazemima postaju onda kad im se doda glagol i valencija: (biti) na dohvat / nadohvat (koga, čega) ili (biti) na domak / na domak (koga, čega). Dakle kako god zapisali navedenu (frazemsku) sastavnicu (tvorenica ili prijedložni izraz), u sastavu se frazema uvijek nalaze više od dvije sastavnice.

Iz korpusa je vidljivo da se imenica domak ${ }^{21}$ gotovo i ne javlja u slobodnoj uporabi, a najčešće je potvrđena s prijedlogom $n a$, pa se prijedložni izrazi na dohvat i na domak mogu smatrati ustaljenima, pa i okamenjenima. Semantička nam analiza tu ne pomaže puno jer razlike između prijedložnih izraza na dohvat i na domak u prijedložnoj funkciji te prijedloga nadohvat i nadomak u rečenicama u kojima se javljaju nema. U starijim se pravopisima ti prijedlozi nisu dovodili u pitanje, a suvremeniji jezični priručnici pokazuju kako pravopisna norma u vezi s njihovim pisanjem, a onda i s morfološkim statusom, nije usklađena. Na ta bismo dva prijedloga ${ }^{22}$ mogli primijeniti pravilo da se sastavljeno pišu prijedlog i imenica ako se imenica ne javlja izvan te veze te da se sastavljeno piše "skup u kojemu se jedan sastavni dio ne upotrebljava uz drugi u onom obliku koji ima u složenici" (BFM 1996: 77). Iz toga slijedi da postoje dva prijedloga: nadohvat i nadomak, a prijedložno-padežni su izrazi ovi: na dohvatu i na domaku. To pravilo ne vrijedi uvijek, pogotovo ako su prijedlog i imenica zadržali svoja osnovna značenja. Međutim da su to uistinu prijedlozi, vidimo po njihovoj među-

\footnotetext{
Tijekom preuzimanja primjera u korpusu HJR-a godina izdanja navedenoga djela nije bila zabilježena.

21 Isto kao i imenica dohvat.

22 Isti problem postoji i s prilozima/prijedložnim izrazima u funkciji priloga. V. Ramadanović (2012: 465-581).
} 
sobnoj sinonimiji (Našli su se nadomak selu i Brod je još bio nadohvat pogled $\left.u^{23}\right)$ i zamjenljivosti s prijedlogom blizu.

\subsection{Uime / u ime}

Tvorenica uime (u- +-ime) propisuje se u ovim hrvatskim pravopisima: 1921: Boranić (PP); 1921: Gavazzi; 1928: Boranić (PP) prij. To plaćamo uime duga.; 1930: Boranić (PP) prij.; 1934: Boranić prij.; 1941: Boranić (PP) prij.; 1941: CGK prij.; 1944: CK (PP) pried. (i rast., ali s drugim značenjem); 1951: Boranić prij.; (PP) To plaćamo uime duga.; 1971: BFM prij.; 1986: AS Govorit ću uime svih.; 1996: BFM prij.; 2001: AS; 2007: BMM prij.; 2013: HPIHJJ prij. (PP) Kazao je to uime kluba. U svim je pravopisima uime prijedlog.

Prijedložni izraz $u$ ime propisuje se u: 1921: Gavazzi pod *za ne valja mjesto u ime (*za bana > u ime bana); 1928: Boranić (PP) Sudi se u ime kraljevo.; 1951: Boranić (PP) Sudi se u ime naroda.; 1960: MH - MS (PP); 2000: BFM (PP) (u čije ime); (PR) pod ime: u ime; 2007: BMM (PP) prij. izraz s prij. funkcijom; u ime Oca; 2008: BHM (PP); 2010: BM (PP) (u čije ime); 2013: HPIHJJ (PP) U ime mi ne diraj, U ime Oca i Sina i Duha Svetoga. Tu je, u većini pravopisa, zapravo riječ o prijedložnom izrazu u osnovnom značenju prijedloga i imenice.

Dakle vidljivo je da se u većini hrvatskih pravopisa uspostavlja razlika između prijedloga i prijedložno-padežnoga izraza, tj. u njima se donosi i tvorenica uime i prijedložno-padežni izraz u ime: 1921: Gavazzi; 1928: Boranić; 1951: Boranić; 1971: BFM; 1986: AS; 1996: BFM; 2001: AS; 2007: BFM; 2013: HPIHJJ (PR: uime < $<$ ime $>$ (Napravit ću to uime $<$ u ime $>$ odanosti, ali Zagledao se u ime na papiru). Pravopisi koji propisuju samo nesastavljeno pisanje (prijedložni izraz u prijedložnoj funkciji) su ovi: 1960: MH - MS; 2000: BFM; 2008: BHM; 2010: BM. Na temelju iznesenoga može se zaključiti da je hrvatska pravopisna tradicija poznavala i propisivala razliku između prijedloga uime i prijedložno-padežnoga izraza u ime. Tu tradiciju zapravo prekida novosadski pravopis 1960. godine koji propisuje samo prijedložni izraz $u$ ime. Zanimljivo je da su izdanja Babić-Finka-Moguševa pravopisa do 2000. godine priznavala status prijedlogu uime, a od izdanja 2000. propisuje se samo prijedložni izraz $u$ ime..$^{24}$

23 Primjeri su preuzeti iz GHJ-a (2005: 222).

$24 \mathrm{U}$ tom je kontekstu zanimljivo spomenuti da prijedlog uime u Čestotniku (1999) ima četiri pojavnice u potkorpusima proze i stihova. Prijedlozi uime i nadomak dva su od deset najmanje čestih prijedloga. Više o tome v. Rišner (2013). 
U leksikografskim je priručnicima prijedlog uime također zabilježen. U HJS-u je zabilježeno ovako: "uime prijed. s G; Uime odanosti, ali U to smo ime nazdravili". Dakle priznaje se status prijedlogu uime, a od njega se razlikuje prijedložno-padežni izraz $u$ ime. Na HJP-u i u HER-u natuknica je tvorenica uime, ali se napominje da se može pisati i nesastavljeno: "ùime (način pisanja uz: u ime) pril. u stalnim vezama riječi [(platiti) uime duga (pozdraviti) uime svih članova društva]". Međutim, u tim je rječnicima uime prilog. U ŠR-u nalazimo zabilježen prijedlog uime u dvama značenjima: 1. 'označuje da tko nastupa umjesto koga drugoga, da zastupa kakvu skupinu' i 2. 'označuje da je što namjera, svrha čemu'. U AŠR-u prijedlog uime zabilježen je kao natuknica sa značenjem 'označuje zastupanje, predstavljanje', ali se u posebnom okviru donosi jezični savjet u kojemu se objašnjava uporaba prijedloga uime te njegova razlika u odnosu na prijedložno-padežni izraz $u$ ime: "vjerovati $u$ ime Gospodnje i pozdraviti uime fakulteta" (A ŠR: 611). U GHJ-u je (2005: 216) potvrđen prijedlog uime kad je riječ o genitivu s prijedlogom uime za koji se navodi da ima značenje "umjestomjesnosti", a u njegovu je značenju "prisutna i predstavljačka nijansa (nije riječ samo o tome da jedan predmet zamjenjuje drugi nego i o tome da drugi predmet predstavlja prvi, često i kao njegov dio)".

Korpus HJR-a bilježi 581 pojavnicu prijedloga uime (primjeri 5a-5c), dok za prijedložni izraz/prijedložno-padežni izraz $u$ ime (6a-6c) postoji 7280 pojavnica, npr.:

(5a) Lovopaziteljima je zaustavljena dvomjesečna plaća uime nadoknade, a zbog nepažnje. (Kovačić 1936).

(5b) [...] koji uime svih sumišljenika-konzervativaca u brošuri Anarhija formulira protivnički [...] (Kušan 2003 (1941))

(5c) [...] kazao je to uime Kluba HDZ-a Ivo Sanader. (NA. Vjesnik online)

(6a) [...] prosim Vaše Veličanstvo u ime sreće i budućnosti svietloga prestolja [...] (Kraljević 2003 (1863))

(6b) Uprite, sokolovi, u ime boga i svetog Nikole! (Šenoa 1999 (1875))

(6c) [...] opunomoćen da u ime divizije pregovaram s njima. (Horvat 1962)

Zanimljivo je primjerice to da prijedlog uime u svezi riječi uime božjel Božje u korpusu nije potvrđen, dok je prijedložni izraz u prijedložnoj funkciji u ime božje/Božje potvrđen u 77 primjera. Za prijedložno-padežni izraz (s prijedlogom uime): uime naroda zabilježene su 3 potvrde, a za skup riječi 
(s prijedložnim izrazom $u$ ime): $u$ ime naroda zabilježeno je 27 potvrda. Za prijedložno-padežni izraz uime kluba (misli se na klubove zastupnika, stranaka i sl.) postoji 96 potvrda, a za skup riječi u ime kluba 532 su potvrde. Međutim, u korpusu je potvrđen samo prijedložni izraz u prijedložnoj funkciji u sintagmi $u$ ime Ocaloca i to u 28 potvrda. Samo u trima od njih nije riječ o početku molitve, npr.: "Članovi Komisije su uočili i neodgovarajuću telefonsku komunikaciju između osobe koja je zvala na odjel $\mathbf{u}$ ime oca dvotjednog djeteta, te odjelnog liječnika" (NA. Vjesnik online).

U korpusu nije pronađena nijedna potvrda za prilog uime ili prijedložni izraz u priložnoj funkciji. ${ }^{25}$ Korpus pisanih tekstova pokazuje da se prijedložni izraz u prijedložnoj funkciji upotrebljava češće od prijedloga te da je u skupu riječi $u$ ime Oca potvrđen samo prijedložni izraz, a to se navodi u HPIHJJ-u te u AŠR-u. Tu se može spomenuti i to da je umjesto prijedloga ispred $\mathrm{u}$ apstraktnom značenju (kad želimo reći da tko nastupa/ govori umjesto koga drugoga ili da zastupa kakvu skupinu) uvijek bolje uporabiti prijedlog uime. Nakraju se ipak zaključuje da je uime prijedlog s G koji kazuje da je ono što stoji u genitivu nečim zamijenjeno, tj. "označuje zastupanje i predstavljanje".

\subsection{USUSRET / U SUSRET}

Tvorenica ususret (u- + -susret) propisana je u sljedećim hrvatskim pravopisima: 1904: BB adv.; 1906: BB adv.; 1921: Gavazzi; 1941: CGK pril.; 1944: CK pril., 1986: AS Izišli su im ususret svojim prijedlozima.; 1996: BFM pril.; 2000: BFM pril.; 2001: AS; 2007: BMM prij.; 2008: BHM pril.; 2010: BM pril.

Prijedložni izraz $u$ susret nalazimo u ovim hrvatskim pravopisima: 1921: Boranić (PP); 1928: Boranić (PP); 1929: PU; 1930: Boranić (PP); 1934: Boranić; 1941: Boranić (PP); 1951: Boranić; 1960: MH - MS (PP); 1971: BFM; 1986: AS Izišli su im u susret na kolodvor.; 1996: BFM.

Vidljivo je da je slučaj proučavanoga prijedloga/priloga suprotan tijeku propisivanja priloga ili prijedloga i prijedložnih izraza u nekim hrvatskim pravopisima. Ham (2002: 69) zaključuje da se od Broza (1892) preko MH MS-a (1960) i BHM-a (1971) do Anić-Silićeva pravopisa 1986. i 2001. popis "složenih frazemskih priloga" povećava, a od pravopisa BFM (1996) taj se

25 Na HJP-u i u HER-u uime je prilog. 
broj smanjuje. Tvorenica (prilog/prijedlog) ususret zapravo je suprotna tom zaključku, tj. BFM (1971) propisuje prijedložni izraz u susret, a od BFM-a (1996) propisan je prilog iako je riječ o frazemskoj sastavnici ( $\diamond$ izići komu u susret/ususret 1 . ispuniti nečiju želju 2. izići na dio puta i prirediti doček onomu tko dolazi).

Iz popisa se vidi da je gramatička odrednica vrste riječi tvorenice ususret prema svim pravopisima - prilog, osim u dvama najnovijim pravopisima: 2007: BFM i 2013: HPIHJJ. U njima se ta tvorenica smatra prijedlogom. Tu je naime riječ o dvjema (ili trima) jezičnim jedinicama: prijedlogu/prijedložnom izrazu u prijedložnoj funkciji, prijedložnom izrazu u priložnoj funkciji i prijedložno-padežnom izrazu u kojem prijedlog $u$ i imenica susret imaju svoje osnovno značenje te iza njih ne slijedi koja promjenljiva riječ.

U jezičnim je priručnicima stanje ovakvo: HJS bilježi üsusret prijed. $s$ D. HER bilježi ususret $\mathrm{s}$ valencijom komu, čemu, ali je ususret po vrsti riječi prilog te se dopušta i nesastavljeno pisanje: "(način pisanja uz: u susret)", a donosi se i frazem: $\diamond$ izići ususret učiniti ustupak, pokazati volju za suradnjom. RHJ bilježi natuknicu usùsret (üsusret) (prij.). Anić ima ùsusret (komu, čemu; pril.). U ŠR-u natuknica ususret je prijedlog, a tako je i u AŠR-u: ususret (komu, čemu) sa značenjem "prema kome, na onu stranu gdje je onaj ili ono s kim/s čim će se suočiti".

Kolebanje u vezi s vrstom riječi tvorenice ususret vidljivo je, osim u pravopisima, i u leksikografskim priručnicima, npr. Anić i HER. Oba rječnika navode da je ususret prilog, a neposredno uz ususret daje se njegova valencija (komu, čemu) što pokazuje da je ususret prijedlog, pa nije jasno zašto je gramatička odrednica za vrstu riječi - prilog.

Kamen spoticanja u toj je riječi i naglasak. U trima jezičnim priručnicima nalazimo dakle naglasno različito zabilježenu promatranu riječ iako se prema pravilima naglasne norme $u$ tim slučajevima naglasak ne treba prenositi na prvi dio tvorenice. Problem je i način na koji se on prenosi (oslabljeno i neoslabljeno $)^{26}$, npr. usùsret $>$ ùsusret (Anić) ili $>$ üsusret (RHJ). ${ }^{27}$

U korpusu HJR-a pronađeno je 380 pojavnica sastavljenoga pisanja ususret i 1095 potvrda za nesastavljeno pisanje $u$ susret. Prijedlog ususret (s D):

\footnotetext{
26 Naglasna norma razumijeva samo prijelaz silaznoga naglaska na proklitiku (tj. u promatranim slučajevima na prvu sastavnicu sraslice). On može biti oslabljen (naglasak postaje uzlazan) i neoslabljen (naglasak ostaje silazan).

27 Za detaljan prikaz i raščlambu naglasnoga stanja tvorenice ususret, ali i nekih drugih v. Matešić i Ramadanović (2017).
} 
(7a) [...] onako huncutski glavom poniknuti i uzmahnuti plešući ususret djevojci [...] (Tomić 1895)

(7b) Tako se pošlo ususret učiteljskim željama. (Binički 1910)

(7c) MARA poleti ususret sinu i ogrli ga [...] (Kosor 1912)

U većini slučajeva u korpusu prijedlog ususret je u postpoziciji:

(8a) [...] crljene brade i brkova skoči mu ususret... (Kovačić 2004. (1888))

(8b) [...] što mu dodju ususret. (Šimunović 1911)

Prijedložni izraz $u$ susret može imati i priložnu funkciju. Međutim u primjerima koji slijede može se reći da je riječ o prijedložnoj funkciji te da je (obično) zamjenica izostavljena:

(9a) Podgorski neopažen približio se u susret te prekinuo tako ovaj razgovor. (Kovačić 1999 (1882))

(9b) Iznenada opazi živo biće gdje se puteljkom, verući se između lisnatoga granja, primiče u susret. (Kovačić 2004 (1888))

Frazem izići (komu) u susret u korpusu je potvrđen u 14 primjera, a izaći (komu) u susret sa 107 primjera. Nije pronađen nijedan primjer $\mathrm{u}$ kojemu je u tom frazemu potvrđena tvorenica ususret.

U leksikografskim je priručnicima, u natuknici susret, zabilježen prijedložni izraz kao frazemska sastavnica: $\diamond$ izići komu u susret 1 . ispuniti nečiju želju 2. izići na dio puta i prirediti doček onomu tko dolazi. Međutim u HER-u i HJP-u u prilogu ususret isti je frazem zabilježen dakle s prilogom kao dijelom frazema: $\diamond$ izići ususret učiniti ustupak, pokazati volju za suradnjom.

U korpusu je katkad riječ i o prijedložno-padežnom izrazu u kojemu $u$ susret nije višerječni prijedlog, nego prijedložno-padežni izraz, tj. prijedlog $u$ s imenicom susret u akuzativu sa značenjem "sastanak, viđenje s kim" ili sport. "natjecanje ili igra dvaju pojedinaca ili momčadi", a to određuje glagolska rekcija. Jedino je u tom slučaju nesastavljeno pisanje neupitno:

(10a) Ovdje se velike nade polažu u susret na vrhu zemalja regije [...] (NA. Vjesnik online)

(10b) Cibona je bolje ušla u susret, uvjerljivom igrom, pogotovo [...] (NA. Vjesnik online)

Između prijedloga i imenice u prijedložnom izrazu $u$ susret $\mathrm{u}$ prijedložnoj funkciji ne može se umetnuti nijedna druga riječ te ta sveza riječi najčešće 
ima prijedložnu funkciju, pa se može zaključiti da je ususret prijedložna tvorenica: ususret (komu, čemu). Kad međutim dolazi uz glagol prijedložni je izraz u priložnoj funkciji. Jezični priručnici bilježe ususret kao prilog i kao prijedlog, pa se može zaključiti da postoje tri jezične jedinice: prilog, prijedlog i prijedložni izraz u osnovnom značenju ili prijedložno-padežni izraz. Međutim u korpusu HJR-a nema potvrde za prilog ususret. Prijedlog ususret označuje "radnju u smjeru koga ili čega", a sinoniman mu je prijedlog prema. Prilog ususret znači "u smjeru koji će uroditi susretom s kim, na onu stranu gdje je onaj ili ono s kim/s čim će se suočiti ili sučeliti".

\section{ZAKLJUČAK}

I ova je raščlamba pokazala i dokazala neusklađenosti i nedosljedne primjene načela za određivanje razlike između izraza u kojima sve riječi čuvaju karakteristike prijedložnoga izraza, tj. kad svaka riječ zadržava svoje puno značenje i funkciju, pa ih zbog toga valja pisati kao dvije riječi (nesastavljeno) i izraza kod kojih se značenje i njihova funkcija mijenjaju, pa se tretiraju kao tvorenice i pišu kao jedna riječ (sastavljeno). S obzirom na to da se u hrvatskim jezičnim priručnicima, ponajprije u onim pravopisnim, razlikuje odnos prema proučavanim prijedlozima, odnosno prijedložnim izrazima, u radu se donose prijedlozi i rješenja proizišla iz opisa i ukupne raščlambe. Istraživanje je pokazalo da kad se za neki prijedložni izraz pokaže da je prijedložni izraz, onda on nije jedna riječ i ne može biti morfološki prijedlog. S druge strane ako zaključimo da su tvorenice nadohvat, nadomak, uime i ususret prijedlozi, a oni to, pokazali smo, jesu, onda ih prema morfološkom načelu treba i pisati kao jednu riječ. Usporedimo li to sa suvremenijim hrvatskim pravopisima, to se rješenje slaže s propisima u trima hrvatskim pravopisima: Anić-Silićevu (2001), Badurina-Marković-Mićanovićevu (2007) i Hrvatskom pravopisu IHJJ-a (2013). 


\section{POPIS IZVORA}

Proučavani i ekscerpirani pravopisi i od njih načinjeni skraćeni zapisi ${ }^{28}$, slijedom objavljivanja:

Kušar (1889) i 1889: Kušar = Kušar, Marćel. 1889. Nauka o pravopisu jezika hrvackoga ili srpskoga. Dubrovnik.

Broz (1892) i 1892: Broz = Broz, Ivan. 1892. Hrvatski pravopis. Zagreb.

Broz (1893) i 1893: Broz = Broz, Ivan. 1893. Hrvatski pravopis. Zagreb.

BB $^{29}$ (1904) i 1904: BB = Broz, Ivan. ${ }^{3} 1904$. Hrvatski pravopis. Prerađeno izdanje, priredio: Dragutin Boranić. Zagreb.

BB (1906) i 1906: BB = Broz, Ivan. ${ }^{4} 1906$. Hrvatski pravopis. Priredio: Dragutin Boranić. Zagreb.

BB (1911) i 1911: BB = Broz, Ivan. ${ }^{51911 . ~ H r v a t s k i ~ p r a v o p i s . ~ P r i r e d i o: ~ D r a g u t i n ~ B o r a-~}$ nić. Zagreb.

Boranić (1921) i 1921: Boranić = Boranić, Dragutin. 1921. Pravopis hrvatskoga ili srpskoga jezika. Zagreb.

Gavazzi (1921) i 1921: Gavazzi = Gavazzi, Milovan. 1921. Pravopisni rječnik s pravopisnim pravilima. Drugo popravljeno i dopunjeno izdanje. Knjižara Kraljevskoga Sveučilišta i Jugoslavenske akademije.

Boranić (1928) i 1928: Boranić = Boranić, Dragutin. ${ }^{4}$ 1928. Pravopis hrvatskoga ili srpskoga jezika. Zagreb.

PU (1929) i 1929: PU = Pravopisno uputstvo za sve osnovne, srednje i stručne škole Kraljevine S.H.S. s kratkim tumačenjem i objašnjenjem. Zagreb. 1929.

Boranić (1930) i 1930: Boranić = Boranić, Dragutin. 1930. Pravopis hrvatskoga ili srpskoga jezika. Peto izdanje, prerađeno prema propisima Ministarstva prosvjete. Zagreb.

Esih (1940) i 1940: Esih = Esih, Ivan. 1940. Hrvatski pravopisni rječnik za pravilnost $i$ čistoću hrvatskoga jezika. Zagreb.

Boranić (1941) i 1941: Boranić = Boranić, Dragutin. 1941. Pravopis hrvatskoga ili srpskoga jezika. Zagreb: Izdanje Nakladnoga zavoda Banovine Hrvatske.

CGK (1941) i 1941: CGK = Cipra, Franjo; Guberina, Petar; Krstić, Kruno. 1941. Hrvatski pravopis. (Pretisak: 1998. ArTresor. Zagreb.)

Klaić (1942) i 1942: Klaić = Klaić, Adolf Bratoljub (uz suradnju članova Hrvatskoga državnog ureda za jezik). 1942. Koriensko pisanje. Zagreb.

28 Uspostavljeni su jer bi ponavljanje punih naslova pravopisa i imena autora stvaralo zalihost te time nepotrebno opteretilo sadržaj. Postoje dva tipa skraćenih zapisa. Prva navedena kratica upotrebljava se u samome tekstu, a oblik skraćenoga zapisa u kojem se godina nalazi slijeva upotrebljava se u tablicama u kojima je zbog kronološke uočljivosti važno da je godina na početku.

29 Broz - Boranić. 
CK (1944) i 1944: CK = Cipra, Franjo; Klaić, Adolf Bratoljub (uz suradnju članova Ureda za hrvatski jezik) 1944. Hrvatski pravopis. Zagreb. (Pretisak: Hrvatski korijenski pravopis. 1992. Zagreb.)

Boranić (1951) i 1951: Boranić = Boranić, Dragutin. ${ }^{10} 1951$. Pravopis hrvatskoga ili srpskoga jezika. Školska knjiga. Zagreb.

MH - MS (1960) i 1960: MH - MS = Pravopis hrvatskosrpskoga književnog jezika s pravopisnim rječnikom. 1960. Izradila pravopisna komisija. Matica hrvatska-Matica srpska. Zagreb - Novi Sad.

BFM (1971) i 1971: BFM = Babić, Stjepan; Finka, Božidar; Moguš, Milan. 1971. Hrvatski pravopis. Školska knjiga. Zagreb.

AS (1986) i 1986: AS = Anić, Vladimir; Silić, Josip. 1986. Pravopisni priručnik hrvatskoga ili srpskoga jezika. Zagreb.

BFM (1996) i 1996: BFM = Babić, Stjepan; Finka, Božidar; Moguš, Milan. ${ }^{4} 1996$. Hrvatski pravopis. Školska knjiga. Zagreb.

BFM (2000) i 2000: BFM = Babić, Stjepan; Finka, Božidar; Moguš, Milan. ${ }^{52000 .}$ Hrvatski pravopis. Školska knjiga. Zagreb.

AS (2001) i 2001: AS = Anić, Vladimir; Silić, Josip. 2001. Pravopis hrvatskoga jezika . Zagreb.

BMM (2007) i 2007: BMM = Badurina, Lada; Marković, Ivan; Mićanović, Krešimir. 2007. Hrvatski pravopis. Matica hrvatska. Zagreb.

BHM (2008) i 2008: BHM = Babić, Stjepan; Ham, Sanda; Moguš, Milan. ${ }^{22008}$. Hrvatski školski pravopis. Usklađen sa zaključcima Vijeća za normu hrvatskoga standardnog jezika. Školska knjiga. Zagreb.

BM (2010) i 2010: BM = Babić, Stjepan; Moguš, Milan. ${ }^{12010 . ~ H r v a t s k i ~ p r a v o p i s . ~}$ Usklađen sa zaključcima Vijeća za normu hrvatskoga standardnog jezika. Školska knjiga. Zagreb.

HPIHJJ (2013) i 2013: HPIHJJ = Hrvatski pravopis. 2013. Institut za hrvatski jezik i jezikoslovlje. Zagreb.

Sekundarni korpus (abecednim redoslijedom):

Anić = Anić, Vladimir. 1996. Rječnik hrvatskoga jezika. Novi Liber. Zagreb.

$\mathrm{AR}=$ Rječnik hrvatskoga ili srpskoga jezika. 1880. - 1976. I-XXIII. JAZU. Zagreb.

AŠR = Anićev školski rječnik hrvatskoga jezika. 2015. Znanje. Zagreb.

BHF = Fink Arsovski, Željka; Kovačević, Barbara; Hrnjak, Anita. 2010. Bibliografija hrvatske frazeologije i CD s popisom frazema analiziranih u znanstvenim i stručnim radovima. Knjigra. Zagreb.

GHJ = Silić, Josip; Pranjković, Ivo. 2005. Gramatika hrvatskoga jezika, za gimnazije i visoka učilišta. Školska knjiga. Zagreb.

HER = Hrvatski enciklopedijski rječnik. 2002. Novi Liber. Zagreb.

HFR = Menac, Antica; Fink-Arsovski, Željka; Venturin, Radomir. 2003. Hrvatski frazeološki rječnik. Naklada Ljevak. Zagreb. 
HG = Barić, Eugenija i dr. 1995., 1997. Hrvatska gramatika. Školska knjiga. Zagreb. HJS = Barić, Eugenija i dr. 1999. Hrvatski jezični savjetnik. IHJJ. Zagreb.

RHJ = Šonje, Jure (gl. ur.). 2000. Rječnik hrvatskoga jezika. Leksikografski zavod "Miroslav Krleža" - Školska knjiga. Zagreb.

ŠR = Birtić, Matea; Bartolec, Goranka Blagus; Hudeček, Lana; Jojić, Ljiljana; Kovačević, Barbara; Lewis, Kristian; Matas Ivanković, Ivana; Mihaljević, Milica; Miloš, Irena; Ramadanović, Ermina; Vidović, Domagoj. 2012. Školski rječnik hrvatskoga jezika. Školska knjiga - Institut za hrvatski jezik i jezikoslovlje. Zagreb.

Mrežni korpusi:

Google $=$ mrežna tražilica (preuzimano od 2. svibnja 2016. do 9. siječnja 2017. godine; s ograničenjem korpusa samo na hrvatski jezik i s domenom - Hrvatska). Primjeri preuzeti s Googlea standardnojezično su usklađeni.

HJP = Hrvatski jezični portal pretraživi je rječnik hrvatskoga jezika nastao kao rezultat zajedničkoga projekta Novog Libera i Srca; na: http://hjp.srce.hr/ (pristupano i preuzimano od 2. svibnja 2011. do 19. prosinca 2012. godine). U jednom je trenutku mrežna adresa toga portala promijenjena: http://hjp.znanje.hr/ (preuzimano do 9. listopada 2016. godine).

HJR = Hrvatska jezična riznica hrvatski je mrežni jezični korpus Instituta za hrvatski jezik i jezikoslovlje.; na: http://riznica.ihjj.hr/

\section{LITERATURA}

Badurina, Lada. 1996. Kratka osnova hrvatskoga pravopisanja. Metodologija rada na pravopisu. Rijeka: Izdavački centar Rijeka.

Blagus Bartolec, Goranka i Ivana Matas Ivanković. 2013. Ispred, iza, u i oko - gdje sve mogu doći prijedlozi. "Rasprave. Časopis Instituta za hrvatski jezik i jezikoslovlje", 39/2, 361-376.

Ham, Sanda. 2000. Pravopisu - ponosu! ili Pravopisu - po nosu!. “Jezik” 47/4, 134-152.

Ham, Sanda. 2002. Sastavljeno i rastavljeno pisanje prijedložnih izraza unutar frazema. Hrvatski pravopis 1892.-2002. "Dometi" 12/1, I-IV, 63-82.

Horvat, Marijana i Ermina Ramadanović. 2007. O tvorbi riječi u Tadijanovićevu djelu Svašta po malo. "Rasprave. Časopis Instituta za hrvatski jezik i jezikoslovlje", 33, 177-196.

Hudeček, Lana i Luka Vukojević. 2005. Sastavljeno i rastavljeno pisanje priloga kao pravopisni i lingvistički problem. Od fonetike do etike: zbornik o sedamdesetgodišnjici prof. dr. Josipa Silića. Ur. Pranjković, Ivo. Zagreb: Disput. 99-125.

Matas Ivanković, Ivana. 2014. Izražavanje prostora i vremena prijedlozima s genitivom u hrvatskom i ruskom jeziku. Zagreb: Institut za hrvatski jezik i jezikoslovlje.

Matešić, Mihaela i Ermina Ramadanović. 2017. Uloga pravopisnih priručnika u standardizaciji pravogovornoga plana. "Rasprave. Časopis Instituta za hrvatski jezik i jezikoslovlje", 43/1, 107-123. 
Minović, Milivoje. 1976. O osnovama savremenih srpskohrvatskih pravopisnih normi u vezi s pisanjem složenica. "Radovi III". Institut za jezik i književnost u Sarajevu. Sarajevo. 221-233.

Moguš, Milan, Maja Bratanić i Marko Tadić. 1999. Hrvatski čestotni rječnik. Zavod za lingvistiku filozofskog fakulteta. Zagreb: Školska knjiga.

Pranjković, Ivo. 2001. Druga hrvatska skladnja. Zagreb: Hrvatska sveučilišna naklada.

Pranjković, Ivo. 2002. Hrvatska skladnja. Drugo, izmijenjeno izdanje. Zagreb: Hrvatska sveučilišna naklada.

Pranjković, Ivo. 2003. Opća načela sastavljenoga i nesastavljenoga pisanja. Hrvatski pravopis 1892-2002. "Dometi" 12, 1/I-IV, 53-62.

Ramadanović, Ermina. 2012. Sastavljeno i nesastavljeno pisanje u hrvatskome jeziku. Doktorski rad. Zagreb: Filozofski fakultet Sveučilišta u Zagrebu.

Ramadanović, Ermina. 2014. Novi pogled na neke stare načine tvorbe riječi (O nekim novim tvorbenim načinima ili o starim na nov način). Sarajevski filološki susreti II (knjiga I). [ur. Palić, Ismail]. Bosansko filološko društvo. Sarajevo. 68-96.

Rišner, Vlasta. 2014. "Rubni” hrvatski prijedlozi. Riječki filološki dani 9: Zbornik radova s Međunarodnoga znanstvenog skupa Riječki filološki dani održanoga u Rijeci od 22. do 24. studenoga 2012. [ur. Diana Stolac]. 563-574.

\section{SUMMARY}

\section{NADOHVAT, NADOMAK, UIME AND USUSRET - THE ORTHOGRAPHIC NOTATION OF PREPOSITIONS IN THE CROATIAN LANGUAGE}

This paper deals with the notation of prepositions in Croatian language textbooks, especially those dealing with orthography. It studies only (selected) prepositions that are problematic in terms of orthography, and their description and analysis are based on several linguistic factors. The starting point is the chapter about the orthography of joined or separated affixes. In view of the fact that the problem of differentiation between one word (a preposition) and several words (a prepositional phrase) is in fact linguistic (composition, morphological and syntactical) and only secondarily a question of orthography, it was necessary to undertake a linguistic analysis. First of all its rules are studied, and they are compared with their description, and in the end with their linguistic usage.

Key words: Croatian language, orthography, combined and separated writing, prepositions, prepositional phrases 